\title{
La fotografía en los procesos de activación y gestión patrimonial. Estudio sobre fotografía tehuelche en Santa Cruz
}

\section{Photography in the asset activation and management processes. Study on photography Tehuelche in Santa Cruz}

\author{
Natalia Marcial, Cristian Bessone \\ natalia862@gmail.com, cbessone@uarg.unpa.edu.ar \\ Universidad Nacional de la Patagonia Austral - Unidad Académica Río Gallegos \\ Av. Piloto "Lero" Rivera y Av. Gdor. Gregores \\ Río Gallegos - Santa Cruz - Argentina
}

Recibido: 04/08/2021. Aceptado: 16/12/2021

\section{RESUMEN}

La imagen fotográfica entendida como artefacto cultural y sistema convencionalizado de representación, constituye en la actualidad uno de los principales focos analíticos de la investigación. En el presente artículo, se exponen los resultados de una pesquisa que analiza la situación del patrimonio fotográfico tehuelche en la provincia de Santa Cruz (Argentina). Para ello, se indaga los archivos y colecciones fotográficas de fines del siglo XIX y principios del XX, a modo de poder reflexionar sobre cómo estas imágenes han influido y determinado diversas identidades étnicas y la construcción de ciertos imaginarios sociales.

Al mismo tiempo, se indaga acerca del rol, usos y sentidos que estos acervos fotográficos pueden representar para los habitantes de la provincia, en tanto que se presentan como una herramienta para la reconstrucción de la memoria y de la generación de vínculos entre el pasado y el presente.

Palabras claves: patrimonio cultural; fotografía; pueblos originarios.

\begin{abstract}
The photographic image, understood as a cultural artifact and a conventionalized system of representation, is currently one of the main analytical focuses of the research. In this article, the results of a research that analyzes the situation of Tehuelche photographic heritage in the province of Santa Cruz (Argentina) are presented. For this, the archives and photographic collections of the late nineteenth and early twentieth centuries are investigated, in order to reflect on how these images have influenced and determined various ethnic identities and the construction of certain social imaginaries.

At the same time, it investigates the role, uses and meanings that these photographic collections can represent for the inhabitants of the province, insofar as they are presented as a tool for the reconstruction of memory and the generation of links between the past and the the present.
\end{abstract}

Keywords: cultural heritage; photography; native peoples. 


\section{INTRODUCCIÓN}

Desde el surgimiento de la fotografía, y tal como lo manifestaba Pérez Winter (2019), se han ampliado sus usos, funciones (artísticas, jurídicas, históricas, científicas) y propósitos, legitimándose como objeto y práctica sociocultural. En ese marco, la fotografía se ha constituido en uno de los principales focos analíticos de numerosos abordajes que desde perspectivas, presupuestos e intereses diversos han enriquecido y jerarquizado la posición de este fenómeno visual.

Ante esto, las fotografías de pueblos originarios han pasado a conformar un complejo patrimonio visual que, bajo el estatuto mimético de la fotografía como imagen, se ha transformado en un registro indesmentible de los aspectos culturales, sociales e históricos. Pero, ¿qué imágenes se nos han mostrado?, ¿qué se representa y especialmente cómo se lo representa? Entendemos que gran parte de estos registros se han realizado bajo formas de lo que la cultura hegemónica eligió como representativo de su identidad y la de los otros, perfilando así una o varias memorias visuales.

Las representaciones, que apuntan hacia las significaciones y las interpretaciones que un sujeto tiene de esa realidad, van a estar condicionadas tanto por el contexto como por las características personales de los individuos, revelando sus intenciones de resaltar o subrayar una parte de la realidad que los ha impresionado. A partir de ello, la hipótesis que guía este trabajo da cuenta que, más que un referente indesmentible de una realidad, las fotografías sobre tehuelches constituyen representaciones que pueden ser interpretadas y resignificadas, permitiendo una conexión entre el pasado y el presente.

En el caso de este trabajo, las hipótesis propuestas en forma general hacen foco en las fotografías sobre los grupos tehuelches en Santa Cruz (Argentina), particularmente de aquellos registros realizados entre fines del siglo XIX y principios del XX.

La presente comunicación, que se realiza en el marco del Proyecto de Investigación (PI) 29/A398 "Revitalización de los saberes populares tradicionales como patrimonio cultural inmaterial en la provincia de Santa Cruz" y que se apoya en la beca de iniciación a la investigación científica de la Universidad Nacional de la Patagonia Austral, se plantea como objetivo explorar el rol, uso y sentido de la fotografía en el campo del patrimonio cultural como forma de acceder a las tensiones existentes en la activación y gestión patrimonial.

La estructura del desarrollo de esta investigación se realiza de la siguiente manera: en primer lugar, se expone el marco teórico donde se definen los conceptos relacionados al patrimonio fotográfico y su vinculación con la producción de imágenes de pueblos originarios. En segundo lugar, se describe el relevamiento exploratorio descriptivo de los acervos fotográficos tehuelches detectados en la provincia y las consultas a informantes claves. En tercer lugar, se presenta los resultados sobre la situación del patrimonio fotográfico tehuelche, la construcción de ese objeto visual, y los usos y sentidos que se le otorgan. En cuarto lugar, se realiza la discusión donde se expone la significación de los resultados que se han descripto. Y finalmente, se expone las principales conclusiones de este trabajo.

\section{MARCO TEÓRICO}

Hablar de patrimonio implica necesariamente hablar de investigación, de inventario, de objetos materiales e inmateriales, de monumentos, de obras de arte, de documentos, de tradiciones, de música y fiestas y del paisaje que los contiene. El bien patrimonial lleva inherentes unos atributos de perdurabilidad y singularidad que provocan fuertes vínculos de pertenencia entre el hombre y su medio y ayudan a encontrar y definir elementos constitutivos de la identidad colectiva. 
El término patrimonio encierra en su significado un sentido de bien heredado, de trasmisión generacional que le confiere un valor añadido (Limón Delgado, 1999). No obstante, si a esta definición la trasladamos del ámbito personal al conjunto social, el significado gana en dimensiones no solo cuantitativas, sino también cualitativas.

La UNESCO (2014) propone una superación del concepto tradicional de patrimonio entendido como monumentos, conjuntos arquitectónicos y lugares de valor universal y amplía su alcance al incorporar lo simbólico, los saberes y creencias, que dota de sentido a los objetos, lo inmaterial.

De esta primera definición, y siguiendo a Perez Winter (2019), las imágenes fotográficas -y los negativos- fueron considerados tempranamente como parte del concepto de patrimonio cultural (material mueble). Es por eso que existen diversos documentos y recomendaciones que promueven su accesibilidad y protección a partir de sus valores históricos, culturales, educativos, artísticos y científicos.

La fotografía, entendida como mensaje sobre un soporte, es decir como documento y como obra de arte, adquiere un doble valor tanto por su continente como por su contenido abierto a nuevos usos e investigación, lo que justifica su tratamiento, protección y conservación. Por esto se la incluye dentro del campo de la gestión del patrimonio cultural, dado que continúa siendo una de las herramientas más utilizadas para el registro y restauración patrimonial; permite registrar y analizar prácticas socio-culturales; y, explícita o implícitamente se reconoce que su constitución en colecciones forma parte de una puesta en valor que requiere preservación -lo mismo que los elementos asociados a su producción.

Gisèle Freund (1999, p.8) definió a la fotografía como "un medio de expresión de la sociedad, establecida sobre la civilización tecnológica, con poder para reproducir exactamente la realidad externa". Esa representación de la vida, de los objetos, de los tipos, paisajes o monumentos, es la clave de su consideración social.

Por tal, la fotografía tiene carácter de documento fotográfico desde que en la toma se genera un mensaje. Es documento abierto. Al contemplar la imagen, el receptor hace una lectura particular, un análisis del que resultarán usos y aplicaciones, por lo que las lecturas serán tantas como las miradas (Vigil, 2012, p. 12)

Ahora, debido a la complejidad y posibilidades de análisis, los archivos y/o colecciones de imágenes fotográficas nos interesan especialmente pues en su conformación y mantenimiento se ponen en juego mecanismos propios de la constitución de imaginarios sociales y sus anclajes en las memorias históricas, así como se instituyen en reservorios culturales susceptibles de atravesar procesos de patrimonialización.

Pero el carácter mimético de una foto no significa que ella sea objetiva o que muestre la "realidad". Dependiendo de la construcción de la mirada que se hace sobre ella, "la fotografía puede ser espejo y espejismo al mismo tiempo" (Pérez Winter, 2019, p. 131). Cabe entonces preguntarse, ¿qué hay más allá de esa apariencia?, ¿qué se nos ha mostrado?, ¿qué se representa? y ¿cómo se lo representa?

\section{Fotografía tehuelche}

En este trabajo se abordan las representaciones fotográficas de grupos o miembros de las comunidades originarias tehuelches entre fines del siglo XIX y principios de siglo XX. Conviene hacer la aclaración de que la denominación Tehuelche se trata de un término impuesto o asignado en mapudungun a dos poblaciones: los Aonik enk que habitaban al sur del río Santa Cruz y los Gününak enk que habitaban al norte del mismo río (Nacuzzi 2007; Rodríguez y Delrío, 2000). Otras clasificaciones más generales, como las de Martínez Sarasola (1992) comparten la definición dada por Escalada (1949) de "complejo Tehuelche" para denominar a los grupos que habitaban la Pampa y la Patagonia hace unos 500 años atrás. 
Esta perspectiva panorámica es una síntesis que ubica a los componentes del llamado "complejo", que quedaría constituida de la siguiente manera: a) Tehuelches septentrionales (Guenaken): continentales; b) Tehuelches meridionales (Penken y Aonikenk): continentales; c) Onas (Selknam y haus): insulares de Tierra del Fuego. A su vez, cada grupo componente presentaba diferencias frente a los demás, pero participaban en conjunto de una forma de vida común por lo cual "se acepta la definición de "complejo" para definirla, teniendo en cuenta además la existencia de una lengua compartida a pesar de las variables dialécticas" (Martínez Sarasola, 1992, p. 64). Esta aclaración nos presenta algunas distinciones significativas en cuestiones que a la postre resultarían claves en elementos identitarios. Sin embargo, los títulos $\mathrm{y}$ distinciones étnicas utilizados por los fotógrafos o por quienes clasificaron con posterioridad las imágenes, bajo el título de grupo tehuelche, ha impedido un mejor detalle socioétnico de estos grupos. Por tanto, se ha considerado conservar esa denominación general para referirnos a las fotografías de estos grupos.

De este modo, bajo el carácter mimético de la fotografía como imagen, la representación de los pueblos aonikenk o tehuelches en Santa $\mathrm{Cruz}^{1}$, forma parte de un registro indesmentible de los aspectos culturales, sociales e históricos. Por ello, este patrimonio debe ser abordado bajo una doble implicancia de significación, material y representacional. Respecto de la materialidad, la producción de imágenes de fines del XIX y principios del siglo XX se realizó de acuerdo a la tecnología, formato y soporte de la actividad fotográfica de la época, lo cual potenció su condición de objeto patrimonial que debía ser resguardado. Pero esa condición se fundamenta en lo que llamamos patrimonio, que para Lorenç Prats (2001) es el resultado de ciertos procesos de construcción de una comunidad respecto de lo que social y culturalmente considera digno de conservación.

Por otro lado, la fotografía como sistema convencionalizado de representación, es decir como una construcción cultural, va siendo significada y resignificada constantemente en los múltiples contextos de circulación y recepción, y en función de las expectativas de quienes experimentan el acto receptivo. Como lo señala Margarita Alvarado (2019, p. 33), al transitar, las imágenes van adquiriendo las más variadas significaciones, demostrando que más que un referente indesmentible de una realidad, constituyen representaciones que pueden ser leídas e interpretadas. Las representaciones, que aluden a un proceso intelectual, cognitivo y cultural apuntan hacia las significaciones, las interpretaciones que tiene el sujeto de esa realidad, las cuales van a estar condicionada tanto por el contexto como por las características de los individuos, quienes revelan sus propósitos de resaltar una parte de la realidad.

Como imagen, desde la producción, el complejo cámara fotográfica/fotógrafo se despliega de acuerdo a las intenciones codificadas de un operador, bajo modalidades visuales propias de los paradigmas fotográficos vigentes en el momento en que fue realizada. Ante esta doble implicancia de significación de la fotografía, en su dupla material/representacional, la construcción del patrimonio visual-fotográfico de los pueblos tehuelches, resulta ser especialmente relevante para comprender cómo y porqué, ciertas fotografías de los pueblos originarios han influido, condicionado y determinado una visualidad de lo indígena, de identidades étnicas, matices, perfiles de culturas y tradiciones.

Ahora bien, en las imágenes de miembros de pueblos originarios, el fotógrafo se constituye en un interlocutor de muchas miradas previas, de imaginarios que proceden incluso de la época hispánica, y que instauraron ciertas marcas de representación de ese "otro" como expresión clara de un colonialismo visual (Giordano, 2007). En esas miradas no participaron los sujetos que constituyen el referente de la imagen: es que ellos no fueron "sujetos" del proceso

\footnotetext{
${ }^{1}$ La población ahonikenk o tehuelche, o gününa küna, involucra una serie de grupos poblacionales a lo largo de Patagonia. En ese sentido, existen registros de estos grupos desde el sur de la provincia de Santa Cruz hasta la zona sur de la provincia de Buenos Aires.
} 
dialógico sino meros "objetos" de representación. De allí que los retratos no llevaban nombres propios, y las imágenes convertidas en postales contenían textos imprecisos y generalizados: "Indios de la Patagonia", "Tehuelches típicos", "Mujeres tehuelches", etcétera. La puesta en escena los muestras rígidos, consternados, resignados, en contraste con la espontaneidad, las mejores galas y las expresiones de superioridad de las familias pioneras.

En este sentido, la situación de dominación entre quien obtura la cámara (grupo hegemónico) y quien es capturado (grupo subalterno) acentúa la violencia ${ }^{2}$ propia de toda toma fotográfica. Entendemos aquí por grupo hegemónico a aquel que introduce e impone sus ideas, les hace creer que son incuestionables los imaginarios, les limitan las posibilidades de florecer desde las pautas de su propia cultura y a la vez de convertirse en sujetos políticos ciudadanizados. Este proceso remite a la colonización de la conciencia como decía Fanon (1980). En tanto, los grupos subalternos son el derivado de una multiplicidad de modos de subordinación que existe entre las sociedades actuales, muchas de las cuales coexisten entre sí: clase, género, edad, etnia, procedencia, entre otras. Es una posición social que cobra cuerpo y cara en los oprimidos.

Por ello, lejos de asumir a la fotografía como una ventana al mundo, la consideramos como una puesta en escena cuyos códigos y marcas de identificación logran una significación, donde la narrativa visual - tal es el caso de los tehuelches- no los contempla como sujetos de la enunciación.

Ante esta ambivalencia entre creación y realidad, estas imágenes han intervenido de manera fundamental en la configuración de ciertos imaginarios y de nuestras memorias visuales, tanto para la sociedad en general, como para los propios pueblos originarios. De manera que la importancia de la fotografía reside no solo en el hecho de que es una creación, sino sobre todo en que es uno de los medios más eficaces de moldear ideas e influir en los comportamientos (Gisele Freund, 1974)

En este aspecto, es central la tarea de los registros patrimoniales locales, que busquen abordarlos en toda su complejidad, lejos de miradas ancladas en la esencia como punto de partida y que hacen de la diversidad algo exótico y que folclorizan la diferencia, la fijan y la aquietan (Álvarez et al, 2014, p. 27). Se trata de entender el patrimonio cultural a partir de los sentidos - diversos y muchas veces con versiones en disputa-, que les otorgan los actores locales considerando sus intersecciones con lo global y con otras expresiones culturales locales (Lacarrieu y Pallani, 2001).

Así, la fotografía puede impulsar a quién la observa a preguntar, a cuestionar, actuar de alguna manera motivada por una imagen que siente que lo interpela. Si bien, la fotografía histórica ha sido considerada como producto de un pasado, también lo es de un presente, que hace visible hasta lo que no aparece en los encuadres fotográficos.

\section{METODOLOGÍA}

La información presentada en esta investigación fue construida en base a una metodología exploratorio-descriptiva sobre los registros fotográficos de tehuelches de fines del siglo XIX y principios del XX. Para ello, se realizó en primer lugar un relevamiento de los archivos y las colecciones fotográficas existentes en la provincia de Santa Cruz. De esta información recopilada, se detectó que una gran parte el legado fotográfico tehuelche se encuentra

\footnotetext{
${ }^{2}$ Para algunos autores, como Susan Sontang (1981), existe una notable asimetría entre quien obtura la cámara y quien es capturado, de manera que la fotografía concierne en sí misma un acto de agresión, pues el sujeto fotografiado es visto como el mismo es incapaz de percibirse, se conoce como no se ha conocido y es transformado en un objeto que puede ser poseído por otros.
} 
disperso, en colecciones públicas como en el Archivo Histórico Municipal de Río Gallegos (A.H.M), o en colecciones privadas de difícil acceso y trazabilidad.

Es necesario aclarar aquí, que el Archivo General de la Nación (AGN) posee también un corpus importante de imágenes de tehuelches, muchas de las cuales procedieron de fotógrafos comerciales y de organismos del Estado, como del Archivo Histórico Provincial de Santa Cruz. Ante esta situación y la imposibilidad de acceder a esos fondos documentales, nos detenemos en la colección que almacena el A.H.M, y en esas imágenes que fueron tomadas bajo distintas modalidades de producción visual por fotógrafos y expedicionarios y que han circulado en diversos contextos discursivos. Esto nos permite comprender las estrategias de construcción simbólica de imaginarios y de representación social de los pueblos originarios (en este caso, tehuelche).

\section{RESULTADOS}

\subsection{Sobre el patrimonio fotográfico tehuelche}

La fotografía del pueblo tehuelche en Santa Cruz, y tal como se mencionó anteriormente se halla en gran parte dispersa. Parte de este legado fotográfico, está bajo la tutela del Estado a través de su principal institución de guarda, que es el Archivo Histórico Municipal de Río Gallegos. El mismo, tiene como finalidad rescatar, clasificar, catalogar, custodiar y poner a disposición de los ciudadanos los documentos generados por el municipio y otras instituciones.

El A.H.M, cuenta en mayor medida con documentos oficiales de la Municipalidad, de una antigüedad de más de treinta años, y de expedientes de otras entidades públicas como el Ministerio de Agricultura y Ganadería de la Nación, del Consejo Agrario Provincial; y otros de carácter privado, fruto de donaciones y compras. Este gran acervo cultural, se encuentra en diferentes soportes: papel, fotográfico y audiovisual.

Actualmente, al año 2021 el Archivo pone a la consulta pública aproximadamente 160 fotografías sobre tehuelches, que fueron adquiridas en el año 2006 mediante compensación de deuda entre el municipio y la familia Roil. ${ }^{3}$ En el acuerdo, el contribuyente (Juan H. Roil) ofreció a la Municipalidad 250 reproducciones de fotografías, de 18 x 24 en blanco y negro, donde se mostraba diferentes aspectos sociales e históricos de la ciudad, a cambio de dicha compensación.

Cabe señalar, que a pesar que se realizó el registro de ingreso de este fondo documental, no se describió cuántas imágenes correspondían a pueblos originarios, por lo que en la investigación se procedió a contabilizar cada una de las fichas de catalogación, de manera manual.

Las fotografías, se resguardan en álbumes, en bolsas de polipropileno y dentro de cajas que contienen las iniciales con las que habitualmente se reconoce el archivo. Estas se encuentran en el Área o Departamento de Documentos Fotográficos, que mantiene las condiciones medioambientales adecuadas para su preservación, entre ellas, aparatos de climatización, iluminación, ventilación, etcétera. Cada una de estas imágenes ha sido catalogada por el Archivo de acuerdo a los criterios de descripción archivística desarrolladas internacionalmente en la década de 1990, y la información recopilada se obtuvo en gran parte del libro "Del Mito a la realidad. Evolución iconográfica del pueblo tehuelche meridional", (1991) de los autores Rodolfo Casamiquela, Osvaldo Mondelo, Enrique Perea y Mateo Martinic. Pese a ello, se observa en muchos casos la falta de información específica del lugar,

\footnotetext{
${ }^{3}$ Walter Roil, fue uno de los primeros profesionales en establecer su estudio fotográfico en Río Gallegos. Fue precisamente el 17 de noviembre de 1934 que abrió sus puertas al público local.
} 
década, e identificación de los miembros que posan delante de las cámaras, lo que dio como resultado la pérdida de los contextos en que fueron generados.

Respecto de las legislaciones que dan cobertura al tratamiento del patrimonio documental, observamos que, tanto a nivel provincial como municipal, se carece de marcos normativos específicos vinculados a los archivos fotográficos. Solo en el Art. 19 de la Ordenanza Municipal № 8043, cuya autoridad de aplicación es el Departamento de Patrimonio Cultural, se habla del Inventario como protección patrimonial que vincula derechos y obligaciones entre la Municipalidad y los particulares, quienes a su vez definen los criterios de valoración de cada bien y área patrimonial. Estos criterios detallados en la normativa han sido clasificados en: a) Integral: protección del bien en su totalidad, conservando la naturaleza, el destino, los usos, y que es aplicable a los bienes inventariados a nivel nacional, provincial y municipal; b) Ambiental: protección del bien y su entorno, y c) Cautelar, que trata de la protección del bien en cuanto a la imagen patrimonial del sector, y aclara que se orienta a la conservación de fachadas, retiros, vegetación, espacios verdes, frentistas y alturas. En tanto, en el Art. 20 se detalla los grados de protección de los bienes, que se refieren a la: a) Conservación; b) Mantenimiento; c) Prevención; d) Salvaguarda y e) Restauración. En las definiciones de cada uno de ellos se menciona los bienes a proteger como obras, objetos, e imágenes. Sin embargo, se toma la "imagen" pero relacionada a lo edilicio y lo urbano. En este aspecto, vemos cómo la ausencia de una política estatal que aborde los archivos fotográficos históricos, refleja tanto la falta de gestión, como la carencia de una normativa procedimental. Estos vacíos son muchas veces cubiertos por el voluntarismo del personal y de los agentes responsables.

\subsection{Los tehuelches frente a las cámaras}

Las primeras fotografías de los aonikenk en el territorio de Santa Cruz fueron efectuadas en el año 1874 por el fotógrafo inglés Peter H. Adams, quien pudo registrarlos como libres cazadores, dueños de la estepa, en sus atuendos típicos, y en el interior de sus toldos. Adams, era un experto fotógrafo que había acompañado en África al explorador David Livingstone en la búsqueda de las fuentes del río Congo y recorrido toda la costa oeste de América, desde Estados Unidos hasta el sur de Chile. Fue precisamente por encargo conjunto de la casa fotográfica Garreaud y Cía. de Santiago de Chile, y los establecimientos Rowsell y Courret de Valparaíso, que Adams realizó tomas del estrecho de Magallanes, Tierra del Fuego y Santa Cruz para confeccionar un álbum de "indios" que se quería publicar. Así, tras haber visitado la colonia de Punta Arenas, llegó en febrero de 1874 hasta el estuario del río Santa Cruz, donde pudo realizar tomas en el paraje Los Misioneros y en la factoría de la isla Pavón. Pero, al no encontrar indígenas viajó hasta el valle superior del Chalía, llegando al paradero de Sehuen Aike, donde finalmente concretó una serie de fotografías de tehuelches y europeos aindiados (Mondelo, 2012, p. 30).

No obstante, en rigor histórico, la primera fotografía de tehuelches fue realizada en Chile $^{4}$ en el año 1863. Un año después, en la galería "Fotografía de Mayo" en la ciudad de Buenos Aires, fueron retratados el cacique Casimiro Biguá y su hijo Sam Slick (Fig.1). De Casimiro, existen otras fotografías, pero de autores y fechas inciertas. Posteriormente, de la década de 1880, proceden algunas imágenes como las del cacique Orkeke, que junto a los niños, mujeres y hombres de su comunidad fueron tomados prisioneros por tropas del ejército argentino, en la cercanía de las Salinas, próximo a Puerto Deseado. Bartolomé Loudet, fotógrafo de la expedición, documentó este último resabio de lo que fuera la campaña del desierto.

\footnotetext{
${ }^{4}$ Las imágenes precursoras de los pueblos originarios de la región Austral del continente, se registraron en Punta Arenas, Valparaíso y Santiago de Chile.
} 
En esta misma época también se registraron iconografías como las de Papón, Mulato y Canario que, reproducidas una y otra vez en formato postal, se utilizaron por largo tiempo para difundir el conocimiento sobre las etnias aborígenes del territorio austral. Si bien es posible advertir que existió una gran variedad de operadores, entre lo que se destacan fotógrafos profesionales, aficionados, antropólogos, exploradores, científicos y geógrafos, son realmente escasas las imágenes con las que actualmente se cuenta en el territorio de Santa Cruz.

Del reservorio documental que almacena el A.H.M, encontramos algunas de las imágenes arriba mencionadas, y otras del paleontólogo Jhon B. Hatcher, que a fines del siglo XIX encabezó una expedición científica con la Universidad de Princenton a la Patagonia. En sus estudios, realizó observaciones geológicas y paleontológicas, pero también registró con su cámara a los tehuelches. Muchos de estos duplicados, fueron guardados en el álbum familiar de William Halliday, ganadero escocés con quien Hatcher había entablado una relación. Sus descendientes, tiempo después facilitaron copias para la reproducción y venta al estudio "Fotografía Roil", de Río Gallegos.

En estas imágenes, el retrato en tanto género que alude a la perpetuación de la memoria individual, grupal o colectiva, presenta cierta contradicción al no identificar a las personas retratadas. Si bien se selecciona el modelo de representación, que se basa en el principio de identificación de la persona retratada se desconoce quién es, de modo que se le agrega a la imagen algunos elementos identitarios, como los toldos, capas o mantas de guanaco (quillango) y animales, que genera una contextualización del retratado que "refleja" -a la manera de espejo, como suponía entonces la fotografía- su identidad. En la mayoría de estas imágenes, y tal como lo señaló Giordano y Reyero (2008) la vestimenta y/ el despojo del retratado opera como dispositivo visual, porque el fotógrafo viste, atavía o despoja al sujeto según intereses compositivos e ideológicos.

Otro aspecto importante de esta construcción del objeto visual, es su homogeneización, ya que todos son uno: "Indios tehuelches". La diversidad se sintetiza en lo "indio", sin interesar la identificación étnica ni la diferenciación intergrupal de las familias, porque la visión se sustentaba en principios raciales y en la construcción de tipos sociales, motivo por el cual no solo la afiliación étnica se negaba, sino como se ha señalado anteriormente, el mismo nombre del retratado.

Asimismo, en la conformación del retrato elaborado con poses corporales, observamos la disposición de las manos, brazos, y objetos que desempeñan un papel en la connotación del grado de actividad. La mayoría de estos sujetos ilustra la recurrencia de las manos y brazos pegados o cruzados al cuerpo, y en algunos casos se incluyen objetos rústicos que suelen aparecer apoyados sobre la tierra, sujeto por las manos de los tehuelches como una extensión de la misma pasividad de sus cuerpos (Fig. 2). También son ejemplos fotográficos los grupos mixtos con sujetos de diferentes géneros y edades. En este aspecto, ese aparente desorden de algunas de estas fotografías no es tal, ya que lo sujetos fueron colocados delante del objetivo, organizados por altura y sexo, portando y mostrando algunos objetos solo para satisfacer la mirada del fotógrafo.

Generalmente, la composición de estas escenas ha sido selectiva y otras veces ambigua con posturas irreales, solo obtenidas para las fotografías (donde se seleccionan solo algunos elementos y posees para la misma). Raramente se observa a tehuelches en una actitud activa, por el contrario, aparecen como salvajes pasivos -sentados o recostados en el suelo o parados con los brazos en reposo junto al cuerpo- de manera que la relación es más de control que de enfrentamiento. Por su parte, a los hombres se los muestra rodeado de mujeres, niños y perros en la entrada de sus toldos, sin que ello marque una cuestión de género o jerarquía guerrera (Fig.3). No obstante, si la fotografía era de un cacique o de un anciano, cualquiera sea su género, éste aparecía solo, remarcando de algún modo una jerarquía que fue solicitada o solo 
existió en el escenario verticalista de quién fotografió, tratando de acercarlos a lo que supuso la propia cultura de pertenencia.

Por ello, las características que presentan estas fotografías resultan de una conjunción de la temática "Tehuelches", a la que aluden con una estética singular que exhibe la composición fotográfica, resultado de la disposición de personajes y espacios, sintetizados en el concepto de salvaje. Esta visibilidad, sin duda pone de manifiesto a sujetos controlados ante la cámara, en las cuales domina la noción de docilidad que une el cuerpo analizable con el cuerpo manipulable.

Así, vemos que las imágenes respondieron a una estética e ideología propia del proyecto modernizador de la época. Tal como lo señalaba el investigador Sergio Caviglia (2001): "Los que llegan deben usurpar una tierra ya ocupada: para ello deben verla como vacía. Entonces se genera una invisibilidad de aquello que no se quiere ver". Aun así, el documento fotográfico (a pesar de ser otra la intencionalidad del pensamiento dominante), parte de la realidad histórica, se filtra y expone más de lo que captó la mirada del fotógrafo.

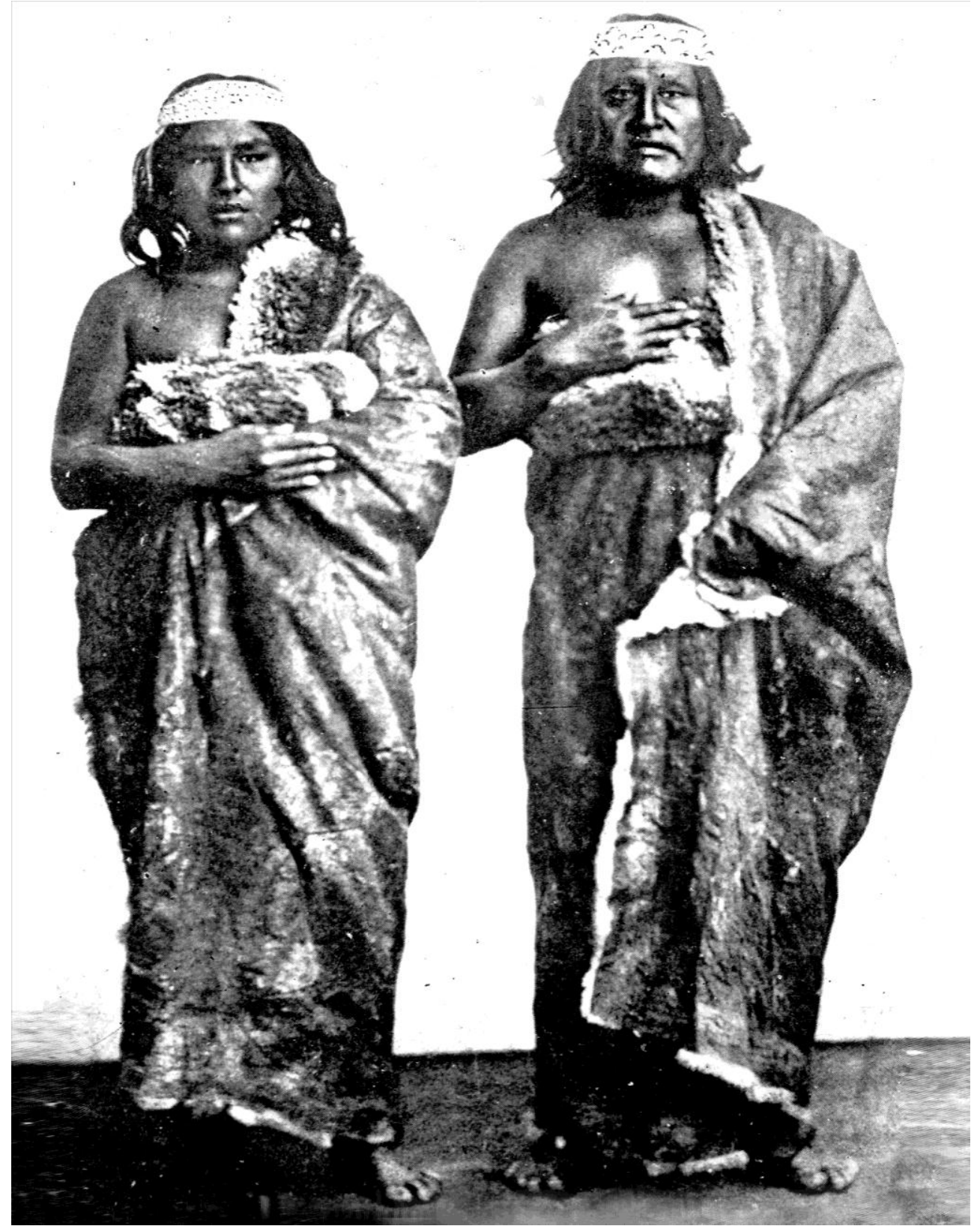

Figura 1: Casimiro Biguá y su hijo Sam Slick. La imagen fue documentada en 1864 en la galería fotográfica "Fotografía Mayo" en Buenos Aires. Foto: Esteban Gonnet 


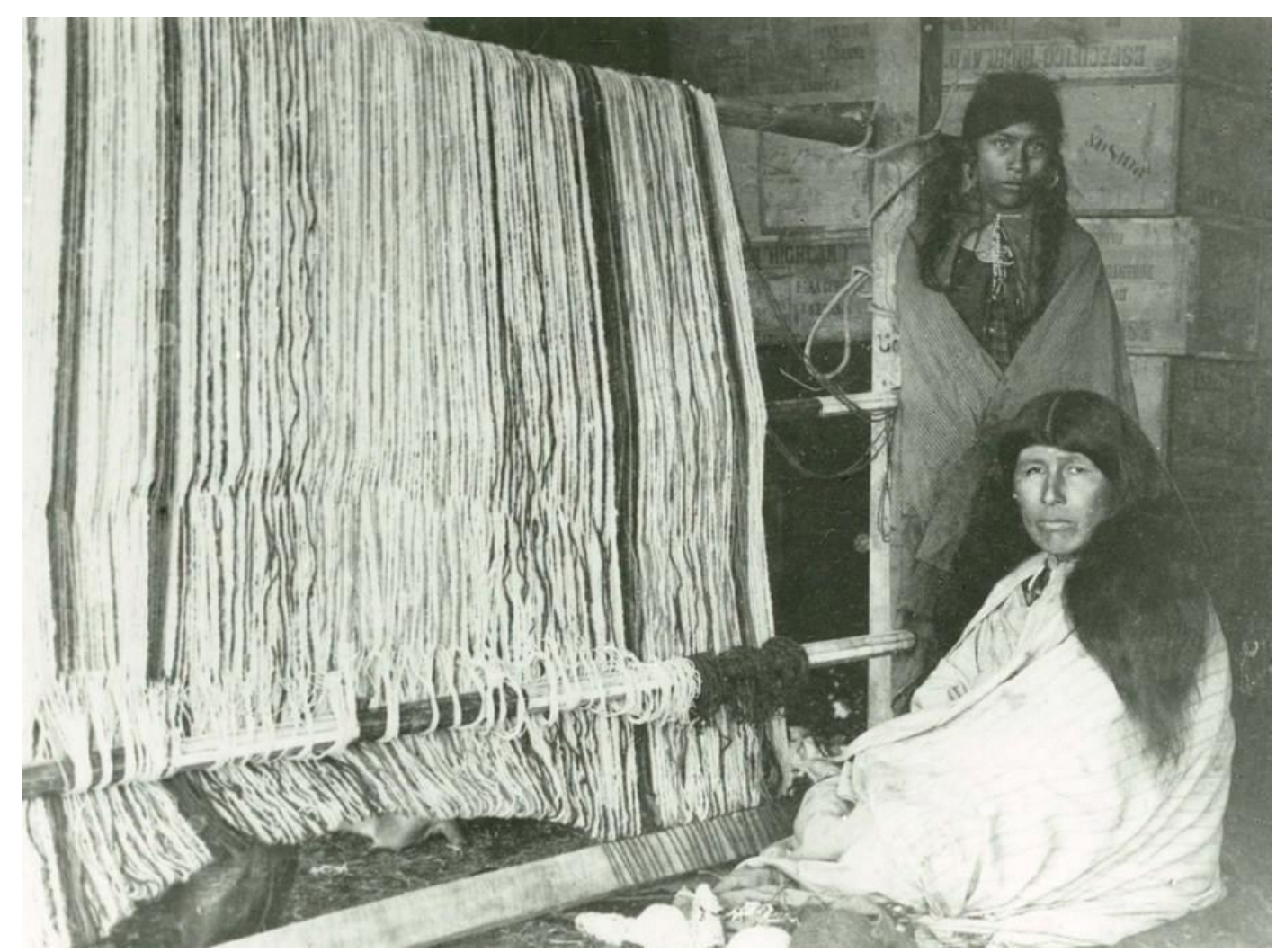

Figura 2: Kamser, tejiendo una manta en telar con su hija.

Fotógrafo: No identificado. Fuente: A.H.M (Sin registro de fecha)

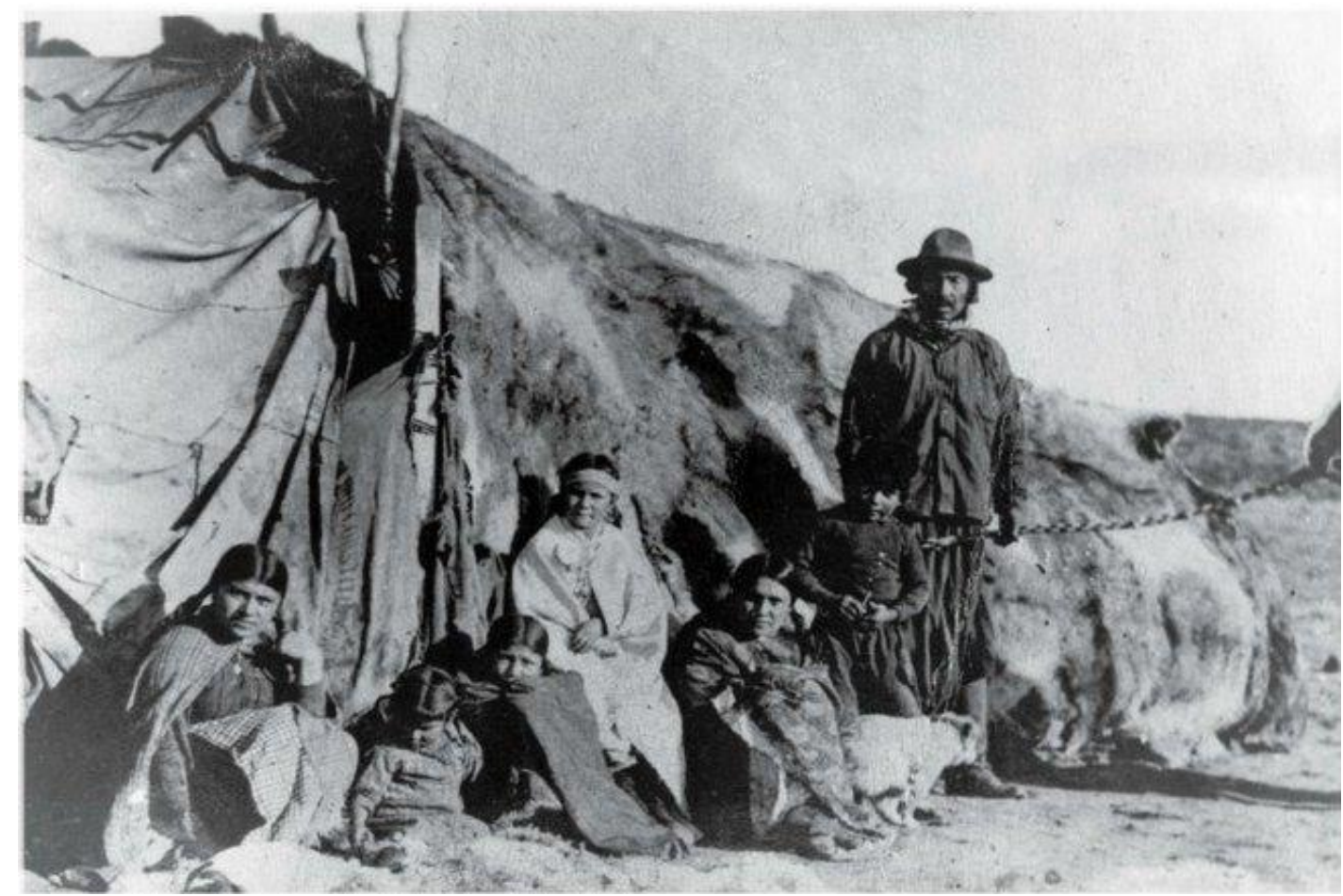

Figura 3: Ramona Lista, su hermana Luisa (Techém), Loóla (de blanco), Catalina Ibáñez (Sujtal), el niño Rufino Ibáñez y Nicolás Ibáñez. Fotógrafo: Francisco Gooderhan. Fuente: A.H.M (Sin registro de fecha) La descripción fue tomada del libro Danza con Fotos, de Osvaldo Mondelo 


\subsection{Sobre los usos sociales de la fotografía tehuelche}

Una cuestión importante para analizar, es la función social que ha tenido la fotografía como "evidencia de la realidad" para ser recordada, mostrada y admirada. Respecto de esta idea, se puede señalar que el uso social de la fotografía está condicionado por la significación que se le otorga, es decir el valor que se le da a la fotografía. En tanto, el fotógrafo como el posante, y los actores que experimentan el acto receptivo son los que le asignan una función específica a la misma. Ahora bien, debido a la complejidad que supone un análisis de ello, nos enfocaremos en los usos que ha tenido la fotografía tehuelche y en las significaciones que son plausibles de construir sobre estas imágenes.

La protección del fondo documental tehuelche en el A.H.M, ha implicado en sí misma una revalorización, pero las acciones tendientes a generar nuevas prácticas, vivencias y sentidos han sido notablemente escasas. Entre ellas, se pueden mencionar las muestras itinerantes que a comienzos del nuevo milenio se constituyeron en una herramienta fundamental para difundir la historia del pueblo tehuelche en los diferentes niveles del sistema educativo de Río Gallegos. No obstante, la exhibición de estas imágenes presentó ciertas particularidades al ser tratadas como simples ilustraciones, reproducidas como en los libros, sin la identificación de los sujetos que aparecían delante de las cámaras y, en muchos casos, descontextualizadas.

Sobre este aspecto es posible advertir que las fotografías sustentaron los discursos escolares, al contar una historia de un "otro", basados en imágenes estáticas y simplificadas, en las que aparecían no solo como personajes de un tiempo remoto (previo a la conformación del estado nacional), sino también bajo posturas esencialistas, y como restos arqueológicos de los antiguos habitantes. Por tal, las fotografías mostraron un registro que estaba inserto en los imaginarios y se traspasaba de generación en generación, condicionado la mirada o más bien la forma de mirar a la comunidad tehuelche.

Estas imágenes que almacena el A.H.M, admiten/requieren diversos trabajos para la memoria local, y en este caso posibilitan ser una herramienta pedagógica de la memoria en la que los alumnos/as puedan establecer un diálogo entre el pasado y el presente, reconocer aquellos elementos identitarios que han hecho marca en la vida del pueblo tehuelche, construir memorias sobre la subjetividad de quienes han desaparecido, poner en tensión determinadas nociones y pensar en otro modo de constitución de los sujetos, ajenos a conceptualizaciones a priori, dándoles así la posibilidad de ser protagonistas de su propio pasado, presente y futuro. Por otro lado, durante el año 2018 y bajo la jefatura de la profesora Isabel Ampuero en el A.H.M, se logró realizar un trabajo de identificación de algunas de las personas que aparecían retratadas. Para ello, se convocó a referentes de la comunidad de Camusu Aike, entre ellos Dora Manchado ${ }^{6}$ que a través de diferentes consultas y experiencias de ver en donde la imagen actuó como un disparador de la memoria, se pudo recuperar y mejorar la catalogación de algunas de las fotografías. Aunque esta tarea no se completó, ni se generaron nuevas iniciativas, esto se debió principalmente a los cambios producidos en la gestión del gobierno municipal, que influyen directamente sobre la administración y los intereses de la institución.

\footnotetext{
${ }^{5}$ La comunidad de Camusu Aike se ubica sobre el cañadón homónimo que desemboca en el sector central del brazo norte del río Coyle, en el Departamento de Güer-Aike, extremo centrosur de la provincia de Santa Cruz. La misma fue creada en el año 1898 como reserva y constituyó la primera del territorio. Actualmente, ya como comunidad desafían la dicotomía rural/ urbano, rechazando el término "reserva" y privilegiando la memoria oral para la demarcación de su territorio.

${ }^{6}$ Fue la última tehuelche parlante, considerada "guardiana de la lengua" por sus contribuciones a la recuperación del aonekko, o como ella misma le llamaba "aukko".
} 
Es importante destacar aquí que la identificación y el reconocimiento identitario de las familias de pueblos tehuelches, posibilita la función de un vínculo generacional, además de que pueden tejerse múltiples tramas de sucesos historizables que forman parte de las narrativas familiares. Como sostiene Catela (2009: 339.), "el uso de la fotografía como instrumento recordatorio de un "afin" ausente recrea, simboliza y recupera una presencia que establece nexos entre la vida y la muerte, lo explicable y lo inexplicable"

Finalmente, en cuanto a tareas de rescate y estrategias de gestión participativa, el Archivo desarrolló durante el año 2020 y en el marco de la pandemia, el concurso anual de fotografía antigua, denominado "Memorias de la ciudad", el cual buscaba acercar el patrimonio local a la comunidad, y a su vez ampliar el fondo fotográfico. El concurso se dio a conocer a través de su fanpage, https://www.facebook.com/archivohistoricoRGL, (Fig. 4) donde se establecieron las bases del concurso y se propusieron una gran diversidad de temáticas a trabajar -entre las que se incluyó desde antiguos pioneros, personalidades y pueblos originarios, hasta monumentos, medios de transporte, costumbres-.

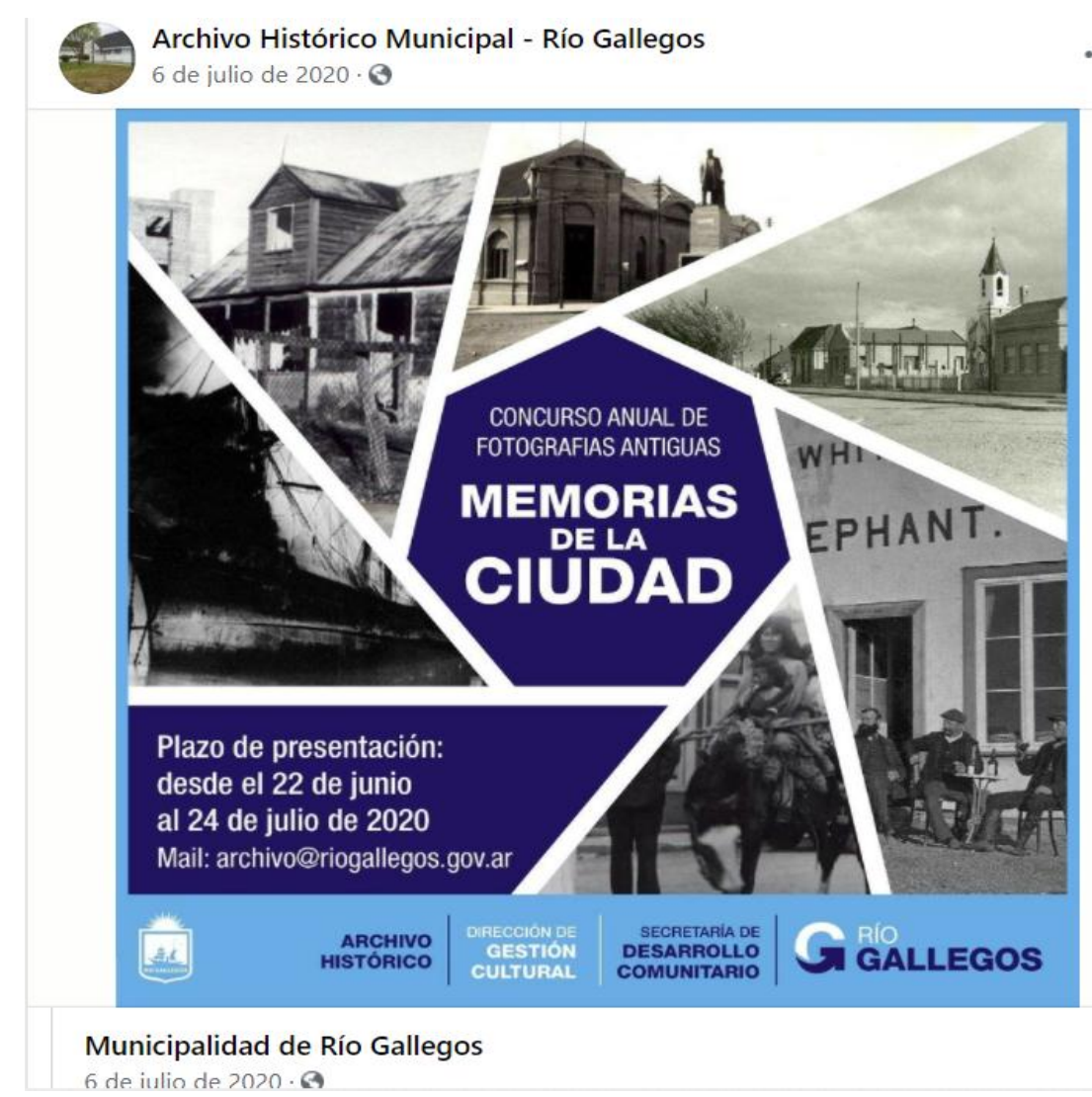

Figura 4: Banners de promoción del concurso fotográfico "Memorias de la ciudad" publicada en la fanpage del A.H.M

En este caso, el concurso a través de Facebook se presentó como una forma de socialización en donde la comunidad pudo participar enviando, o dejando las fotografías en el A.H.M para ser digitalizadas, lo que posteriormente permite conformar nuevos archivos públicos. Aunque durante la propuesta no se registraron imágenes de pueblos originarios, este espacio habilitó la oportunidad de ampliar, actualizar y construir colectivamente otras versiones de la historia local.

Así, mediante esta interacción de compartir y hacer disponibles imágenes fotográficas, que frecuentemente son acompañadas de relatos y recuerdos que la comunidad aporta, se otorgan sentidos, se construyen otras lecturas, representaciones y acercamientos con el pasado más inmediato. 


\section{DISCUSIÓN}

De acuerdo a los resultados observados, en primer lugar y en relación a los acervos sobre fotografías del pueblo tehuelche, en Santa Cruz son más bien escasos en relación a otros conjuntos fotográficos. En las instancias relevadas, sólo en el A.H.M encontramos este legado iconográfico. En este lugar, gran parte del archivo está insuficientemente catalogado, por ausencia de información original, pero también por la carencia de criterios claros y específicos para su uso (no hay identificación exhaustiva de los retratados, al tiempo que no se observa un registro ordenado de las imágenes). De manera que la función del archivo se restringe a la función únicamente de guarda, siendo en este caso un repositorio más de fondos y documentos mayoritariamente estatales.

Al mismo tiempo se observa que, en relación a otro tipo de fotografías, como la de los llamados "pioneros", la fotografía de pueblos originarios ha estado relegada en su resguardo, difusión y puesta en valor.

En la provincia, el conjunto de bienes culturales gestionados desde una perspectiva patrimonial cuenta con normativas desde la década de 1990, sin embargo, las acciones derivadas de este marco legal desde entonces al presente, han sido muy generales en tanto el tratamiento dado a las normativas también lo es. Por tanto, no es de extrañar que, aunque la misma conceptualización de patrimonio se ha ido transformando y ampliando, aun no se cuenta con normativas específicas para trabajar con archivos fotográficos o audiovisuales en Santa Cruz. Esto significa que los archivos fotográficos son abordados sin una contención adecuada, ya que el acopio por sí solo no es suficiente. No solo en relación a su preservación material, sin las cuales no se sería posible desencadenar otras fases interpretativas, sino también desde una gestión integral que posibilite su puesta en valor.

Por otra parte, en cuanto a las fotografías de tehuelches de fines del siglo XIX y principios del siglo XX, observamos que estas fueron parte de un ejercicio -ampliamente repetido respecto a los pueblos originarios a lo largo del país-, en el que la mirada del fotógrafo (grupo hegemónico) se hizo en base a posiciones estéticas, ideológicas y colonizadoras respecto de los sujetos fotografiados (grupo subalterno). En gran medida, las imágenes muestran las marcas del exotismo -los toldos, quillangos y animales- que el imaginario social esperaba de los indios tehuelches, considerados por entonces como reliquias vivientes de un mundo en extinción. ${ }^{7}$ Quedan pendientes preguntas en torno a los momentos de producción y a la relación existente entre cada operador fotográfico y las personas fotografiadas, que exceden largamente lo que puede rescatarse a partir del documento visual, pero que sería clave conocer. Entre otras cosas, en el Archivo General de la Nación existen algunas fotografías similares a las existentes en el AHM, de los catalogados como "tehuelches" o "mapuchetehuelches" que responden a la forma en que eran mirados por los expedicionarios, científicos, gobernantes, misioneros, fotógrafos y trotamundos que recorrían la zona. En cambio, la relación existente entre los fotógrafos locales y estos grupos, en convivencia relativamente cercana, adquiere otra dimensión que sería conveniente indagar en investigaciones venideras.

En relación a ello, podemos percibir que estas imágenes que la cultura hegemónica eligió como representativas de su identidad, fueron las que intervinieron de manera fundamental en la configuración de ciertos imaginarios y de las memorias visuales, tanto para la sociedad en general, como para los propios pueblos originarios, sobre todo en cuanto a sus identidades

\footnotetext{
${ }^{7}$ Este mundo en extinción tiene varios referentes, pero puede mencionarse el inicio de estas descripciones con las de Ramón Lista (1998), que se refiere sin eufemismos a la trágica y progresiva desaparición del grupo tehuelche por la tisis, la sífilis, el alcohol y la desaprensión de las autoridades argentinas y chilenas de la época respecto a este y otros grupos de pueblos originarios.
} 
étnicas. No obstante, destacamos aquí, que reflexionar sobre la memoria permite generar nuevas percepciones e interpretaciones que posicionan a estos grupos como agentes de cambio frente a las estructuras de colonización que operaron desde fines del siglo XIX.

Respecto de los usos sociales de la fotografía tehuelche en el A.H.M, observamos que existen notables limitaciones en cuanto a su capacidad para producir y difundir significados. Esto lo vemos, por ejemplo, en las muestras fotográficas itinerantes que, a pesar de ser un recurso excepcional para desarrollar en el sistema educativo, aún no se han trabajado a fondo. Las formas en que fueron presentadas las fotografías en dichas muestras se enmarcan en los discursos históricos acerca de la extinción del pueblo tehuelche. En este sentido, estos reservorios suscitan trabajos como la activación de la memoria a través de exposiciones con seguimiento y estudios de recepción que puedan confirmar la permanencia de imaginarios o la pérdida por olvido. Nos preguntamos si podrían participar otras voces en la elaboración de las muestras, teniendo en cuenta la existencia de comunidades locales que responden a la continuidad de estas identidades grupales, o a la construcción de la propia identidad santacruceña. En esta línea, resaltamos el trabajo realizado en 2018 por el AHM con referentes de la comunidad de Camusu Aike, que mediante diferentes consultas y procesos de identificación permitió mejorar la catalogación de algunas de las fotografías. No obstante, este trabajo no se acabó por cambios en la gestión de gobierno municipal, y quedaron pendientes no solo completar la catalogación sino realizar también unos trabajos más profundos sobre la resignificación de esas imágenes en tanto pueden contribuir a la sociedad santacruceña a contextualizar los cambios y las continuidades, a tomar conciencia sobre los silencios, los olvidos, los no dichos y los ocultamientos que dejaron huellas en las memorias colectivas.

Estas consultas y participaciones no son menores. Prueba de ello son las directrices plasmadas a nivel nacional y que indican que antes de implementar cualquier medida que sea susceptible de afectar directamente a los pueblos originarios, el Estado debe realizar una consulta previa, libre e informada a las instituciones representativas, dado que es un derecho previsto en el Convenio 169 de la OIT sobre Pueblos Indígenas y Tribales en Países Independientes ${ }^{8}$ y de la Declaración de las Naciones Unidas sobre los Derechos de los Pueblos Indígenas 9 .

Por último, vemos que la conformación de un archivo audiovisual virtual se presenta como una alternativa para proteger, salvaguardar y difundir las imágenes en el marco de un escenario extremadamente dinámico, y en consideración de los propios soportes físicos, que pueden degradarse si no se tienen los cuidados necesarios. Los acervos fotográficos digitales nos abren nuevos planteamientos acerca de la gestión de los mismos, dado que cuando no se piensa profundamente en todos sus usos potenciales, se puede caer en la pérdida total del acceso a la imagen.

\section{CONCLUSIÓN}

Como hemos expuesto en este trabajo, el patrimonio fotográfico del pueblo tehuelche en Santa Cruz es realmente escaso y está en un constante proceso de construcción y resignificación. De manera que, problematizar sobre la forma en cómo estas imágenes han influido y determinado diversas identidades étnicas, es importante no sólo para poder indagar sobre la construcción de las memorias y las narrativas históricas regionales, sino también para

\footnotetext{
${ }^{8}$ El Convenio 169 de la OIT fue aprobado por ley 24.071 en 1992 y ratificado en 2000. Rige en Argentina desde el 3 de julio de 2001 y es una de las herramientas jurídicas más importantes para la defensa de los Derechos Indígenas.

${ }^{9}$ En www.un.org/esa/socdev/unpfii/documents/DRIPS_es.pdf
} 
impulsar las instancias de consulta y participación que se debe realizar a los miembros de las comunidades, sobretodo en cuanto a su resguardo, conservación y puesta en valor.

En el caso de esta investigación, constatamos que las fotografías sobre tehuelches de fines de siglo XIX y principios del XX, han devenido de un proceso de prácticas materiales institucionalizadas visualmente, que al tiempo que otorgaron identidad regularon y disciplinaron. Por lo tanto, es posible advertir que la producción de imágenes del pueblo tehuelche ha contribuido a la construcción de la memoria del otro (grupo subalternoindígenas) que, como bien se señaló, se hizo de acuerdo a los medios técnicos, bajo las modalidades propias de los paradigmas fotográficos vigentes y de una ideología del nosotros (como grupo hegemónico). En este sentido, las imágenes que se mostraron respaldaron un registro que estaba inserto en los imaginarios y que se traspasó de generación en generación, condicionado la mirada o más bien la forma de mirar a la comunidad tehuelche.

Ahora bien, observamos que este reservorio documental que almacena el A.H.M demanda diversos trabajos para la memoria local, y en particular se presenta como un recurso excepcional para desarrollar en los diferentes niveles del sistema educativo, donde los alumnos/as, pueden resignificar, contextualizar y colaborar para que los grupos revivan lazos de pertenencia colectiva, y a su vez tomen conciencia sobre el pasado, el presente y el futuro. Asimismo, mediante estas fotografías los tehuelches pueden reelaborar sus imaginarios y memorias compartidas desde la multiplicidad de pertenencias sociales, posicionándolos así como agente de cambio.

Finalmente, el hecho de haber trabajado con imágenes, nos hace pensar en las diversas dimensiones y vinculaciones que constituyeron la vida del pueblo tehuelche. Reconocemos que cada una de estas imágenes han sido soporte de las memorias singulares y colectivas, con tensiones y diversas miradas sobre el otro, que nos habla y nos interpela a seguir construyéndola, ya que como dice Pierre Nora (2009: 20): "la memoria es la vida, siempre encarnada por grupos vivientes y, en ese sentido, está en evolución permanente, abierta a la dialéctica del recuerdo".

\section{BIBLIOGRAFÍA}

ALVARADO P. M. (2019). La imagen de lo extraño: fotografía, patrimonio visual y pueblos indígenas del sur de américa. Base Diseño E Innovación, (4), 30-39.

ÁLVAREZ, P., BESSONE, C., y KULEMEYER, J. (2014). El nuestro social. Patrimonio y gestión. Apuntes de un proceso cambiante. UNPAEdita, Universidad Nacional de la Patagonia Austral.

BATCHEN, G. (2004). Arder en deseos. La concepción de la fotografía. Barcelona: Editorial Gili S.A.

BERGER, J. (1998). Mirar. Bs.As.: De la Flor.

BURKIN, V. (2004). Ensayos. Barcelona: Editorial Gili.

CARRASCO, M., y CARDIN, L. (Eds.) (2018). Campos de interlocución y políticas de reconocimiento indígena en Argentina. Argentina: EA.

CATELA, L. (2010). Fotografía e identidad: captura por la cámara, devolución por la memoria. Bs.As.: Nueva Trilce.

CAVIGLIA, S. (2001) El mundo a través de uno mismo. La fotografía etnográfica en la Patagonia, 1860-1950, IV Congreso de Historia Social y Política de la Patagonia Argentino- Chilena.

EDWARDS, E., \& HART, J. (2004). Photographs objects histories. On the materiality of images. Nueva York: Routledge. https://doi.org/10.4324/9780203506493

ESCALADA, F. (1949). El complejo «tehuelche» estudios de etnografía patagónica. Coni. 
FANON, F. (1980). Los condenados de la tierra. México: Fondo de Cultura Económica

FREUND, G. (1999). La Fotografía como documento social. Barcelona: Gili.

GIORDANO, M. (2007) Falsas imágenes, falsas memorias en la fotografía etnográfica. IVCongreso Internacional de Teoria e Historia del Arte - XII Jornadas de CAIA Buenos Aires, CAIA

GIORDANO, Mariana Lilian; REYERO, Alejandra Paola Yanina, (2008) Mostrar y mostrarse: La construcción de memorias visuales e identidades étnicas desde los grupos hegemónicos chaqueños; J. Suriano

LACARRIEU, M. y PALLINI, V. (2001) La gestión del patrimonio(s) Intangibles(s) en el contexto de políticas de la cultura. En Primeras Jornadas de Patrimonio Intangible. Memorias, identidades e imaginarios sociales: 81-104, Buenos Aires: Comisión para la preservación del Patrimonio Histórico Cultural de la ciudad de Buenos Aires.

LIMÓN DELGADO, A. (1999). Patrimonio ¿de quién? En E. Aguilar Criado (Ed.), Patrimonio Etnológico, Nuevas perspectivas de estudio (pp. 8-15). Granada: Consejería de Cultura. Junta de Andalucía.

LISTA, R. (1998). Los indios tehuelches: Una raza que desaparece (1. ed.). Editorial Confluencia.

MARTÍNEZ SARASOLA, C. (1992). Nuestros paisanos los indios: Vida, historia y destino de las comunidades indígenas en la Argentina. Emecé.

MONDELO, O. (2012) Tehuelches, danzas con fotos. El Calafate

NACUZZI, L. R. (2007). Nomadic groups of the Patagonia and Chaco regions in the XVIII century: identities, spaces, movements and economic resources in the face of european contact. A comparative reflection. Chungará (Arica), 39(2), 221-234. https://doi.org/10.4067/S0717-73562007000200005

NORA, Pierre (2009). Les lieux de mémoire. Santiago de Chile: LOM EdicionesTrilce.

PÉREZ WINTER, C. (2019). La fotografía en los procesos de activación, resignificación y gestión patrimonial.Sophia Austral, (23), 129-151. https://doi.org/10.4067/S0719$\underline{56052019000100129}$

PRATS, LL. (2001). El concepto de patrimonio cultural. Cuadernos de antropología Social No11, pp. 115 - 136. Universidad de Buenos Aires.

RODRÍGUEZ, M. E. y DELRÍO, W. (2000). Los tehuelches. Un paseo etnohistórico. En VVAA. El gran libro de la Provincia de Santa Cruz, Barcelona, Alfa-Milenio.

SONTAG, S. (1996) "Sobre la Fotografía". Traducción de Carlos Gardini. Editorial Edhasa, Barcelona.

TAGG, J. (2005). El peso de la representación. Barcelona: Editorial Gili.

UNESCO. Cartas de UNESCO. disponibles en: http://portal.unesco.org/es/ev.php-

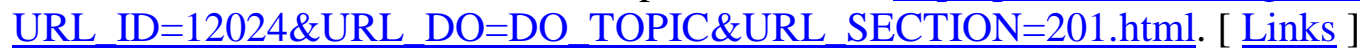

UNESCO (2014). Indicadores de cultura para el desarrollo. Manual Metodológico. París: UNESCO

VIGIL, J. M. S. (2012). La fotografía: patrimonio e investigación. Artigrama (27), 25-35 


\section{ANEXO}

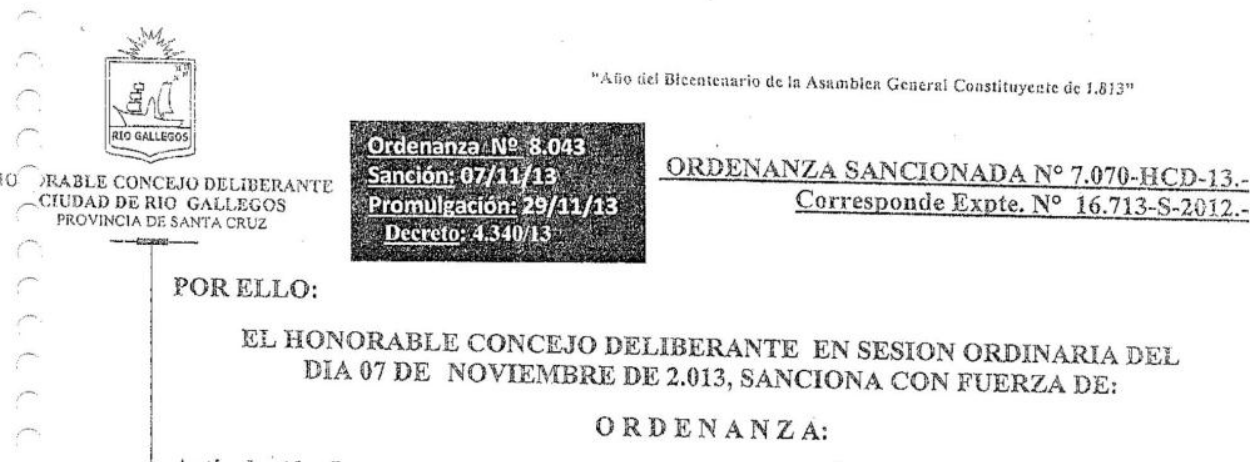

Artículo $l^{0}$ - La presente Ordenanza es de aplicación en toda la jurisdicción territorial de Río Gallegos, denominada ejido urbano, en virtud de lo establecido en el Artículo $8^{\circ}$ de la Ley $N^{\circ} 3.138$. Sus disposiciones se aplicarán a la propiedad privada, pública y a las personas de derecho público cualquiera fuera su naturaleza juridica y la afectación de sus bienes.

La presente Ordenanza tiene carácter de orden público atento al recurso, cultural, ambiental y económico objeto de protección.

Artículo $2^{\circ}$ - No podrá ser derogada por convenios entre particulares, y todo acto administrativo que se dicte por el Departamento Ejecutivo a propuesta del organismo de apiicación, y que tenga por objeto aclarar o interpretar la presente Ordenanza, deberá ser aplicada por todos los organismos municipales con competencia concurrente en la materia.

Artículo $3^{\circ}$ - El patrimonio cultural de la Municipalidad de Rio Gallegos está integrado por las obras del hombre, las obras conjuntas del hombre y la naturaleza y los recursos naturales que forman parte del ejido, los usos y costumbres, los paisajes culturales y todos aquellos bienes que posean un carácter histórico, antropológico, etnográfico, arqueológico, artístico, arquitectónico urbano, científico e inmaterial incluido el patrimonio natural y cultual viviente. Estos caracteres no son restrictivos, y pueden adoptarse otros mediante Ordenanzas que se sanciones en el futuro.

a) El patrimonio cultural tangible está constituido por bienes muebles e inmuebles, como así los bienes muebles accesorios a los inmuebles.-

b) El patrimonio cultural intangible está integrado por los usos, representaciones, los saberes y las técnicas, y los espacios culturales que le son inherentes desarrollados por la comunidad o grupo de personas representativa de la diversidad cultural y de la creatividad del municipio.

Articulo $4^{\circ}$. - Son objetivos de esta Ordenanza:

a) Velar por la preservación de patrimonio cultural, arquitectónico, arqueológico, histórico, natural e intangible.-

b) Icentificar el Inventario y su correspondiente registro para asegurar la conservación, el fomento, ia investigación y la difusión que garantice la participación y el acceso del ciudadano al

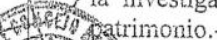

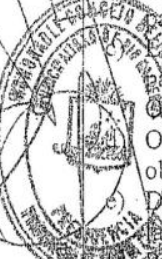

ablecer el procedimiento administrativo de delimitación de áreas y de declaratoria de bienes Gmoniales y los mecanismos de gestión para asegurar el cumplimiento de la presente angenanza.

Ordepan la conducta de los propietarios de inmuebles de valor patrimonial, dirigicla a la obligación de conservar en buen estado de seguridad y salubridad.-

0 / S3.5 romover la coordinación inter-administrativa entre

los organismos con competencia en

g) Crear los mecanismos de participación ciudadana a la comunidad generai en cuestión relativas al patrimonio cuitural y natural.

\section{TITULO SEGUNDO \\ DE LAS ÁREAS PATRIMONIALES}

Artículo $5^{\circ}$-. Se entiende como distrito de zonificación patrimonial al poder de policía municipal 7070

"LOS WIELOS CONTINENTALES, L.AS ISLAS MIALYINAS, ANTARTIDA E ISLAS DEL ATLANTICO SUR, SON ARGENTINOS"

\section{OEPTO. ACTMMAD PARLAMENTARIA}

HONORAELE CONCENO BELIBERANTE 

TA DE SANTA CRUZ

$$
\ldots 2 \ldots
$$
dirigida a controlar la edificación, los usos, la estética, la técnica, las condiciones de higiene o de
salubridad de la Municipalidad de Río Gailegos.-

Axtículo $6^{\circ}$ - DELIMÍTAS en el ejido de Río Gallegos con una superficie mínima de hectárea las áreas patrimoniales, coincidiendo con el amanzanamiento en el Catastro Municipal que diversidad u homogeneidad valores históricos, ambientales, paisajísticos, culturales, etc., y por su

Artículo $7^{\circ}$.- EL Área de Protección Patrimonial conforme lo establecido por la Ley № 3.138 , se encuentra vinculado en el ejido con los siguientes distritos de zonificación:

a) Área de Protección Patrimonial Instituciones: es un 'rea integrada por edificios institucionale de carácter público o privado, algunos Declarados Monumentos Históricos Provinciales, que proveen diversos servicios municipales, educativos, religiosos, de uso cívico, judiciales, administrativos, postales, de esparcimiento etc., y su entorno conforme plano que como Anexo, forma parte de esta Ordenanza. Incluye: como Anexo II: APP1.

b) Área de Protección Patrimonial Ex-ferroportuaria: es el área donde se desarrolló la activida portuaria y ferroviaria de X.C.F y los bienes integrantes del ex ferrocarril y el ex servicio portuario. También forma parte del área el conjunto de viviendas de Yacimientos Carbonfferos Fiscales con la Iglesia denominada "Virgen Niña" y los terrenos.

c) Remanentes por la Avenida Balbín (ex vía férrea) hasta la autovía "17 de Octubre" conforme la delimitación establecida en el plano que como Anexo I forma parte de esta Ordenanza. Incluye: como Anexo II APP2.

d) Area de Protección Patrimonial Costanera: es el área de esparcimiento de la ciudad, tambiér es fundacional y la misma estará subdivida en tres subzonas. Se sujetará a las Ordenanzas ambientales vigentes en la materia cuya aplicación en concurrente conjetará a las Ordenanzas la Municipalidad de Rio Gallegos. Incluye: como Anexo II APP4.

\section{TITULO TERCERO}

\section{DE LOS PARÁMETROS URBANISTICOS PATRIMONIALES}

Articulo $8^{\circ}-$ Principios Generales: Definiciones:

a) Factor de Ocupación Total (F.O.T) aquella definida por la Ordenanza Municipal № 3.259 Sancionada en el año $1.998 \mathrm{en}$ su art. 1-1.

b) Factor de Ocupación del Suelo (F.O.S) en forma análoga es el establecido en la Ordenanza mencionada precedentemente.-

Categorías de Uso son establecidos por la Ordenanza № 3.259 en sus Código de la Edificación Según Ordenanza $N^{\circ} 3.259$.

FATUURA: la altura máxima no podrá superar la altura original de las construcciones preexistentes, en aquellos casos que requiera la intervención en edificios patrimoniales ppeviamente valorados como tales deberá formular la consulta ante el Órgano de aplicación de
osta norma.-

11. 1 on de aplicación no se autorizará la construcción de una superficie nueva mayor a la mitad de la superficie preexistente.-

f) En todos los casos como órgano asesor en asuntos patrimoniales se realizará la consulta incluyendo a las asociaciones vecinales constituidas ene le área patrimonial, respecto de los retiros, usos y otra intervención constructiva.-

g) RETIRO: se mantendrán los retiros originales de las edificaciones preexistentes.-

$$
\text { roro }
$$

"LOS HIELOS CONTINENTALES, LAS ISLAS MALVINAS, ANTARTIDA EISLAS DEL ATLANTICO SUR, SON ARGUNTINOS"

\section{DEFTO ACTWDAD PARLAMENTARIA}

\section{HONORABU CONOSWO BCL IBERANTE}




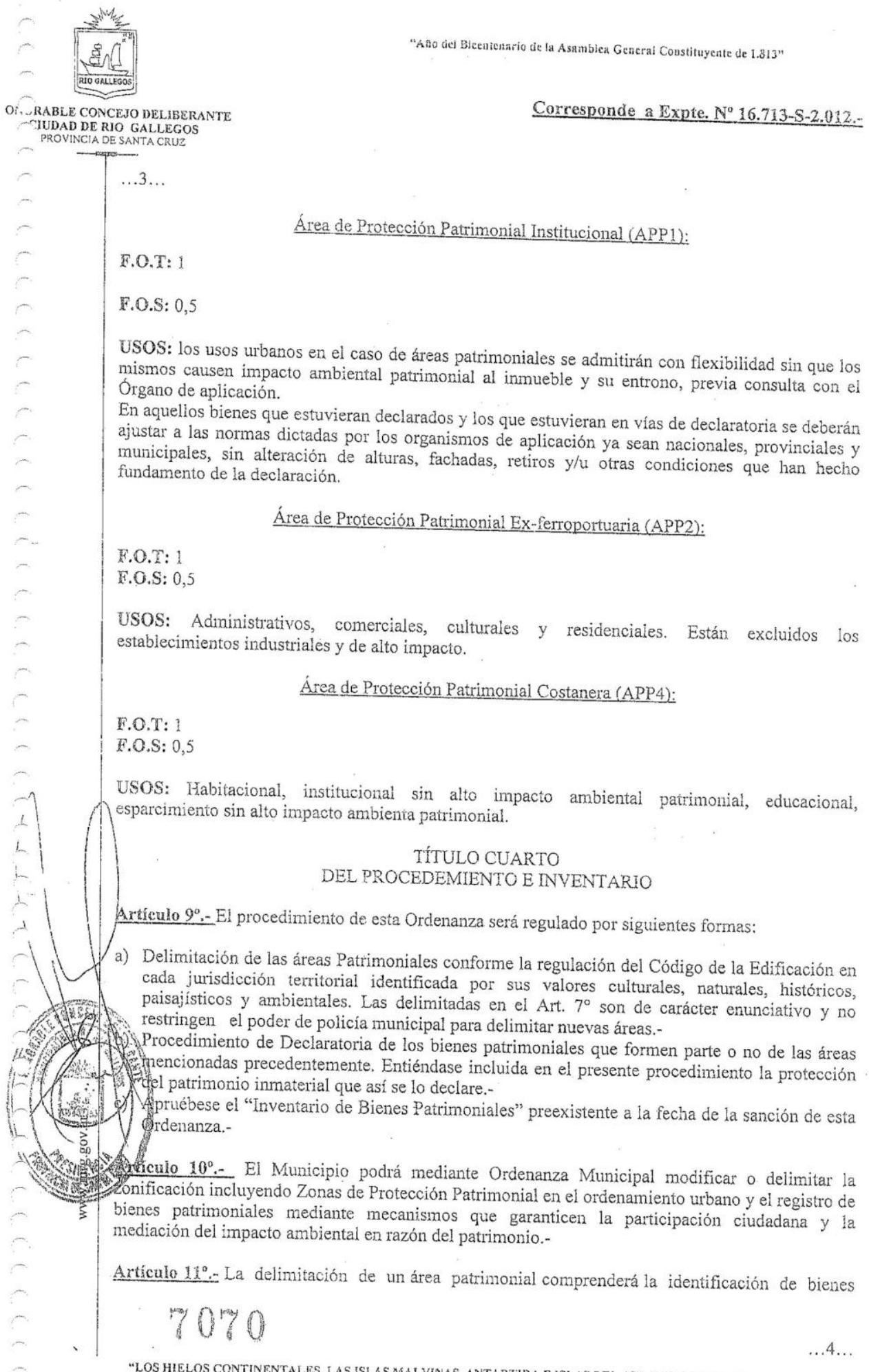

"LOS HIELOS CONTINENTALES, LAS ISLAS MALVINAS, ANTARTIDA E ISLAS DEL ATLANTICO SUR, SON ARGENTINOS"

\section{DEPTO. ACTHOAD PATLAMENTARIA HONORABUE CONCSNO BSLIBERANTE}


$\ldots 4 \ldots$

cuiturales y ambientales que por sus valores integren el Inventario del Patrimonio Cuttual, Arquitectónico, Urbano y Natural; incluyendo los parámetros urbanísticos propios de estal, Planeaniento Urbano.- previo dictamen del organismo de aplicación y del Dirección de

Artículo $12^{\circ}$. Loas estándares urbanísticos de esta zonificación especial son los siguientes:

a) Obligación de conservar el bien con limitación de altura, densidad, tipología urbana acorde a la manzana en los bienes inmuebles patrimoniales identificados en el Inventario.-

b) Proporcionalidad entre bienes de uso público y privado.

c) Adecuación a la Ley de Medio Ambiente de $\mathrm{N}^{\circ} 2.658$ y decreto reglamentario.-

d) Adecuación a la Lay $N^{\circ} 3.138$, a la Ley $n^{\circ} 3.137$ y a la clasificación efectuada por la Comisión Nacional de Museos, Monumentos y Lugares Históricos.-

e) Establecimiento de un Régimen de Estímulos, Beneficios y Sanciones al efecto.Artículo $13^{\circ}-$ El procedimiento de declaratorio deberá observar lo establecido en el Art. $10^{\circ}$ y
siguientes de la Ley $N^{0} 3.138$.-

Artículo $14^{\circ}$ - La obligación de conservar y ejecutar obras en bienes inmuebles patrimoniales inventarios, previo dictamen del organismo aplicación y en el supuesto de bienes del dominio privado deberá contratarse a un profesional acreditado especialista en la materia a su cargo. En los y proyecto.-

Artículo $15^{\circ}$ - En aquellos bienes inventariados en los cuales por distintas circunstancias podría ponerse en riesgo la integridad del mismo, de su entorno o del área patrimonial al que es de ambiental patrimonial.-

Artículo 16.- En los casos de áreas patrimoniales reguladas por esta Ordenanza Municipal, la Municipalidad de Río Gallegos ejercerá el poder de policía urbanístico mediante un sistema de control de la obligación de conservar y; las facultades de imposición que establezcan exenciones de fas contribuciones o aumento de la cuota contributiva según correspondiere por el perjuicio o el peneficio económico obtenido. En este caso se reglamentara mediante la Ordenanza tarifaria anual.-

inventaria ${ }^{\circ}$ - El patrimonio de carácter inmaterial, cualquiera fuere su naturaleza, deberá ser 5 k/ 1 conforme los criterios propios que datos que al efecto se elabore por el organismo de aplicación, criter propios que adopte la Municipalidad de Río Gallegos.-

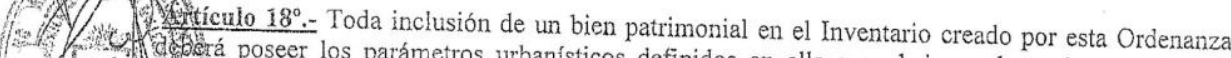
4) a debiendo acreditarse con fundros urbanísticos definidos en ella y su baja es de carácter restrictivo - 13 meligro a los linderos y deteriamentos técnicos los problemas de seguridad edilicios, estructurales,

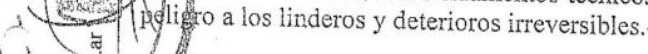

Lesponiculo $19^{\circ}$ - El Inventario como instrumento de protección patrimonial que vincula derechos y Dada bien y área patrimonial, a saber:
cas particulares establecerá los Criterios de Valoración de है.

a) Integral: es la protección del bien en su totalidad, conservando la naturaleza, el destino, los usos y que es aplicable a los bienes inventariados con nivel nacional, provincial y municipal. Cabe a esta designación solo intervención de restauración, no admitiéndose ampliaciones.

$$
7070
$$

"LOS HIELOS CONTINENTALES, LAS ISLAS MALVINAS, ANTARTIDA E ISLAS DEL ATLANTICO SUR, SON ARGENTINOS" 